ISSN 1112-9867

\title{
MODELING OF ZAKAT IN THE CAPITAL STRUCTURE THEORY
}

\author{
N. A. Sanusi ${ }^{1, *}$, A. G. Talattov ${ }^{1}$, S. Kusairi ${ }^{1}$ and A. H. S. M. Nor ${ }^{2}$ \\ ${ }^{1}$ School of Social Development and Economics,Universiti Malaysia Terengganu, 21030 \\ Kuala Terengganu, Terengganu, Malaysia \\ ${ }^{2}$ School of Economics,Universiti Kebangsaan Malaysia, 43600 Bangi, Selangor, Malaysia
}

Published online: 10 November 2017

\begin{abstract}
Islamic financial instruments are subject to taxes and zakat for Muslim shareholders and debt holders. Therefore, it is important to investigate the implementation of corporate taxes and corporate zakat in capital structure compositions. In order to model corporate zakat in terms of conventional capital structure theories, this study will discuss the conventional view of those theories in depth. The introduction of zakat are based on the conventional static trade-off theory developed by previous researchers.
\end{abstract}

Keywords: wealth tax; optimal capital structure; Islamic financial instrument.

\section{INTRODUCTION}

The most important business decisions that a financial manager has to make are the capital structure and the tax deductions. There is ample empirical evidence on the way financial managers make capital structure decisions [3, 6, 12, 15, 30-31, 35]. The tax deductions also received much attention. Most of the empirical literatures[6, 8-9, 13, 22-23]focus on the benefits of tax.

Author Correspondence, e-mail: nurazura@umt.edu.my

doi: http://dx.doi.org/10.4314/jfas.v9i6s.67 
Even though payment of tax is a common practice for many firms, the tax puzzle remains a controversial issue in the corporate finance literature. This is mentioned by [5-6, 11, 33-35]as: "tax deduction encourages firm to utilize debt and hence encourage bankruptcy". An alternative for tax payments is to pay zakat (or wealth tax). Until now, most of the literature has viewed the tax benefits and the zakat payments in isolation. However, the tax deductions and the zakat payment are both expected to influence capital structure decisions.

There is a large body of theoretical literature on capital structure. From this literature, it can be concluded that corporate tax is an important factor in making capital structure decisions. A firm that utilizeshigher debt financing is likely to pay less tax. The most important distinguishing factor between the forms of payment consists of zakat. The fact that traditionally equity financings are treated less favorably than debt financings has given rise to the earlier mentioned tax puzzle. This puzzle was created by the fact that firms pay less tax on the one hand and are exposed to risk of bankruptcy in the form of higher interest payments on the other. The next question on whether zakat leads to an a priori advantage or disadvantage for the utilization of debt financings by firm is unclear. Managerial option plans are expected to reduce debt financings because they increase current liabilities and therefore the amount of zakat.

In this research, we try to develop model of Islamic capital structure theory by taking the zakat payment into account. Conventional capital structure theory just focuses on the static trade-off theory, agency conflicts theory and pecking order theory. More specifically, this study will focus on the introduction of zakat in the conventional static trade-off theory developed by [7, 23]. Malaysia is of particular interest, since it is the only country in the world where zakat payments are deducted from income tax. Another interesting aspect of the Malaysian market is that a large number of firms do pay zakat. The combination of these two facts leads to an interesting sample that includes firms that only pay tax and firms that pay both tax and zakat.

\subsection{The Traditional Capital Structure Theory}

The discussion of capital structure started with [24], who argued that capital structure decisions cannot affect firm value. In a perfect market, leverage choices have no impact on 
value and managers who imperfectly operate markets are acquainted with how an imperfect market could manage to decide among choices of capital structures.

Furthermore, in [24] begin by making several assumptions about capital structure and firms. These assumptions simplify their analysis and focus it entirely on the valuation effects of debt. However, they argued that capital structure composition was considered irrelevant to a firm's market valuation.

\subsection{Proposition I without Taxes}

The M\&M Proposition I without taxes stated that for perfect markets, the total market value is the same as the value of its assets, which is referred to as the company's capital structure independence. The value of assets is the same as the present value of cash flow resulting from the assets. Since the proposition suggests that the capital structure of a firm is not an issue. This condition is recognized as the "irrelevance proposition".

In addition, as the first assumption explained previously, when it has no taxes and good capital market function, it creates no contrast whether the firm takes on debt or not. Thus, the market value of a company is independent of its capital structure, i.e. $V_{L}=V_{U}$.

$\mathrm{V}_{\mathrm{L}}=\mathrm{V}_{\mathrm{U}}=\frac{\mathrm{EBIT}}{\mathrm{r}_{\mathrm{A}}}=\frac{\mathrm{EBIT}}{\mathrm{r}_{\mathrm{EU}}}=\frac{\text { EBIT }}{\mathrm{r}}$

where $V_{\mathrm{L}}$ : levered firm value, $\mathrm{V}_{\mathrm{U}}$ : unlevered firm value, EBIT: earnings before interest and taxes (net operating profit), $\mathrm{r}_{\mathrm{A}}$ : the weighted-average cost of capital (WACC) and $\mathrm{r}_{\mathrm{EU}}$ : the equity cost on unlevered firm.

Equation (1) represent that the market value of any firm does not depend on a firm's capital structure. Instead, it is defined by emphasizing the expected net operating income at the rate $\mathrm{r}$. Moreover, utilizing an arbitrage argument, M\&M proved Proposition I. The "no-arbitrage principle" where M\&M's argument rests, states that market prices must be adaptable in equilibrium, even at the point where there are no arbitrage opportunities at all. M\&M also argue that if the value of a levered firm is different from that of its identical, unlevered counterpart, arbitrage can be carried out. Since arbitrage opportunities cannot last long, the two firms have to have the same value in the equilibrium. 


\subsection{Proposition II without Taxes}

The second significant insight is that despite debt raises smaller number of costs in issuing that kind of equity. Referring to Equation (1), the relationship between the returns of levered equity $\left(\mathrm{r}_{\mathrm{EL}}\right)$, debt $\left(\mathrm{r}_{\mathrm{D}}\right)$ and unlevered equity $\left(\mathrm{r}_{\mathrm{EU}}\right)$ can be written as:

$\frac{E}{E+D} r_{E L}+\frac{D}{E+D} r_{D}=r_{E U}$

Solving for $\mathrm{r}_{\mathrm{EL}}$ the next equation for the return of levered equity can be retrieved:

$\mathrm{r}_{\mathrm{EL}}=\mathrm{r}_{\mathrm{EU}}+\frac{\mathrm{D}}{\mathrm{E}}\left(\mathrm{r}_{\mathrm{EU}}-\mathrm{r}_{\mathrm{D}}\right)$

Equation (3) shows how changes in debt and equity result in change in a firm's value. Specifically, the second term of the equation signifies the extra risk added because of leverage. Therefore, the extra risk a firm stimulates ultimately depends on the quantities of leverage a firm holds, i.e. the debt-equity ratio (D/E). In addition, Equation (3) also points out that when the debt ratio increases, equity cost will increase because shareholders take on higher risk and thus ask for a higher rate of return. Furthermore, the WACC will remain constant, and so will the value of firm. In other words, the capital structure is independent of the value of firm. Finally, Equation (2) brings up the second proposition of [25] for whom "the cost of capital of levered equity is equal to the cost of capital of unlevered equity plus a premium that is proportional to the market value debt-equity ratio".

\subsection{Proposition I with Taxes}

As previously discussed, in [25] already have established the irrelevance of a firm choosing a capital structure in perfect capital markets. The following section will introduce an important source of friction, taxes, into the M\&M framework. Interestingly, five years after their original work in 1958, they came out with a new study in 1963. The former was corrected by the latter, in which tax consideration was omitted from their theory. As a result, firms are able to increase their value by using debt to decrease taxes. If a firm tries to utilize debt, the need to pay interest on that debt decreases corporate taxes. Consequently, the taxes are an incentive for a firm to use leverage. The firm's value is considered based on its leverage or capital structure.

If the author lets $\mathrm{V}_{\mathrm{U}}$ and $\mathrm{V}_{\mathrm{L}}$ be the value of the firm without and with leverage respectively, the changes can be shown in the following Equation (1) which requires taxes to be created: 
$\mathrm{V}_{\mathrm{U}}=\frac{\operatorname{EBIT}\left(1-\mathrm{T}_{\mathrm{C}}\right)}{\mathrm{r}_{\mathrm{EU}}}$

$\mathrm{V}_{\mathrm{L}}=\frac{\operatorname{EBIT}\left(1-\mathrm{T}_{\mathrm{C}}\right)}{\mathrm{r}_{\mathrm{EU}}}+\mathrm{T}_{\mathrm{C}} \mathrm{D}$

$\mathrm{V}_{\mathrm{L}}=\mathrm{V}_{\mathrm{U}}+\mathrm{T}_{\mathrm{C}} \mathrm{D}$

Equation (6) shows a levered firm's total value over that of the unlevered one because the tax savings present value in the form of debt financing (tax advantage of debt). Furthermore, based on the assumption that the corporate tax rate is greater than zero and interest payments can by deducted from taxable income, Equation (6) also suggests that only with $100 \%$ debt can an optimal capital structure be achieved. Thus, the equation represents that if $T_{C}$ is constant, the firm's value grows linearly with D because of tax benefits.

\subsection{Proposition II with Taxes}

Furthermore, the following proposition shows that equity cost is dependent on its leverage.

$\mathrm{r}_{\mathrm{EL}}=\mathrm{r}_{\mathrm{EU}}+\frac{\mathrm{D}}{\mathrm{E}}\left(\mathrm{r}_{\mathrm{EU}}-\mathrm{r}_{\mathrm{D}}\right)\left(1-\mathrm{T}_{\mathrm{C}}\right)$

Equation (7) is almost identical to Equation (3) (Proposition II without taxes) and the difference is $\left(1-\mathrm{T}_{\mathrm{C}}\right)$. Furthermore, since $\left(1-\mathrm{T}_{\mathrm{C}}\right)<1$, the effect of tax will raise the equity cost but it will then decrease slowly, so that the weighted-average cost of capital (WACC) decreases and at one level it will increase.

\subsection{The M\&M Model with Corporate and Personal Taxes}

There are some academics such as [23] who have discussed the relationship between taxes and debt, stating that tax advantage earned by a corporation in terms of debt is waived by the leverage personal tax disadvantage. In [23] considers personal taxes so that he can show that the " $100 \%$ debt" implication is irrelevant.

Furthermore, Equation (6) leads to the tax profit of leverage where a corporation must pay taxes. Individual interest payments earned from debt are taxes as income. This is what should concern the corporation. Under this condition, dividends and capital gains had to be paid by investors. Because of that, just as with corporate taxes, personal taxes deplete the cash flows to investors. This results in investors reducing the value of a firm. Thus, the actual interest tax shield is in accordance with the total tax reductions between personal and corporate taxes paid. Furthermore, in [23] also explained that tax advantage of debt over equity at the 
corporate level could be offset by the non-benefit tax at the individual level either fully or partially.

Synthesizing differences in corporate income tax rates as well as personal tax rates on interest, dividends and capital gains, in [23] produced the following formula to estimate the gains by including leverage.

$\mathrm{V}_{\mathrm{L}}=\mathrm{V}_{\mathrm{U}}+\left\{1-\left[\frac{\left(1-\mathrm{T}_{\mathrm{C}}\right)\left(1-\mathrm{T}_{\mathrm{PS}}\right)}{\left(1-\mathrm{T}_{\mathrm{PD}}\right)}\right]\right\} \mathrm{D}$

Tax shield $=\left\{1-\left[\frac{\left(1-\mathrm{T}_{\mathrm{C}}\right)\left(1-\mathrm{T}_{\mathrm{PS}}\right)}{\left(1-\mathrm{T}_{\mathrm{PD}}\right)}\right]\right\} \mathrm{D}$

where $\mathrm{T}_{\mathrm{C}}$ : tax rate within corporate profits, $\mathrm{T}_{\mathrm{PS}}$ : personal tax rate on income on stock (equity income), $\mathrm{T}_{\mathrm{PD}}$ : personal tax rate on income on debt (interest income) and $\mathrm{D}$ : market value of the corporate outstanding debt.

Equation (9) helps resolve the seeming conflict between leverage and taxes. Consequently, while debt is profit at the corporate level since it decreases a firm's tax burden, the impact of debt income for personal taxes could increase, decrease or even reverse the beneficial effects over debt financing as all of them are based on the equity income personal tax rate on debt. For instance, the tax can even be even negative if the interest income $\mathrm{T}_{\mathrm{PD}}$ is larger than the corporate tax rate $\mathrm{T}_{\mathrm{C}}$ and equity income $\mathrm{T}_{\mathrm{PS}}$.

\subsection{The M\&M Model and Non-Debt Tax Shield}

Coming after [23], several researchers also established tax-based extension of the basic capital structure models. It is also worth noting that [8] included non-debt tax shields (NDTS) as a substitute for debt in corporate financial structures. Their NDTS premise states that firms that experience enormous depreciation, investment tax credits and research and development expenditures as well as other forms of NDTS had better utilize a smaller amount of debt financing than an equivalent firm with fewer shields.

This hypothesis on secured debt has been theoretically and empirically supported. More recent work on the subject has already covered how to measure NDTS's separate effect and also the assets that can be collateralized, support both NDTS and the secured-debt hypotheses $[10,14,22,32]$.

\subsection{The M\&M Model and Financial Distress}

As discussed before, previous studies have indicated that firms fail to completely exploit the 
debt tax advantage. There are some suggestions; one of them is opting for low leverage levels at which the financial debt is accompanied by specific costs that preclude firms from exploitation, especially in term of interest tax shields. It means that the optimal leverage cannot be determined only by taxes.

Furthermore, the discussion will then proceed to deal with financial distress, i.e. the largest cost of financial debt. In conclusion, the level of debt financing is proportional to the probability of default. Putting taxes aside, another crucial distinction between financing debt and equity lies in the debt payment. The debt payment has circumvent potential bankruptcy, otherwise dividend payments or capital gains can be restrained by firms. Especially, if there is distressis probability where for firm, it is supposed to be costly, those cost could counterbalance the tax advantage of debt financing. Consequently, the M\&M model must consider the financial distress costs as market imperfections and include them when looking at the capital structure decisions of firms. Later, in [23] realized that there is impact of bankruptcy cost on capital structure decisions.In the next paper, this author supposes that the influence made on costs is more marginal than a very large benefit resulting from tax shields of leveraged firms.

Fear resulting from bankruptcy is caused by so many financial debt. It leads to why tax benefit of debt are seldom exploited. A large number of reported works have come out with research on the impact of bankruptcy risk on a firm's capital structure decision. Those reports basically have different variable choices used to determine whether there is potential for bankruptcy. However, in [16] reasoned that bankruptcy “...occurs when the fixed obligations to creditors cannot be met. It this case, there is a transfer of ownership and a formal reorganization of the capital structure of the firm. The costs associated with this transfer can be categorized as either direct or indirect. Direct costs include legal, accounting and trustee fees as well as the possible denial of income tax loss carryovers and carrybacks. Indirect costs relate to opportunity costs resulting from disruptions in firm-supplier or firm-customer relationships that are associated with the transfer of ownership or control".

\subsection{The Presence of Zakat in Malaysian Business}

As discussed previously, the most crucial reason for firms to increase the amount of debt is the tax shield resulting from the tax savings gained from paying interest on the debt. Hence, using debt, a firm's estimated tax liability could be reduced. Consequently, increasing the cash 
flow after taxes leads to more profits and the ability of a business to assume a higher debt level. Eventually, the higher debt level can be employed in order to raise a debt tax shield for those firms. Nevertheless, there is an alternative for tax payments namely zakat payments [37].

Until now, the discourse on zakat payment and zakat in general have been progressively extending throught business environment. However,in [37]have considered zakat payments as an influence on capital structure decisions. However, tax deductions and corporate zakat payments are both expected to influence the capital structure decisions. Furthermore, Malaysia is one of the few countries in the world where corporate zakat payments are deducted from the income tax [2, 4, 36]. Moreover, in [2] asserted that more Malaysian firms are becoming more interested in fulfilling their zakat obligations.

According to [2], the administration of zakat is handled by the states through their respective State Islamic Religious Councils (SIRCs). Zakat itself is regulated under the authority of the respective state or the prerogative rights of the Sultan. Last but not least, those rules are valid except for the Federal Territory where the Federal government supervises the administration and law of zakat. In accordance, every state arranges its own zakat matters including the collection method, disbursement policy, administrative aspects, execution and degree of enforcement.

However, there is a main zakat principle for corporate wealth that is in accordance of merchandise goods ('urud al-tijarah), equal to anything obtained with the aim of achieving benefits for a corporation. The wealth which has fulfilled the requirement and reach nizab must become zakatable. In this case, nizab is equal to monetary value of 85 grams of gold. Once both nizab and the calculation value are completed, zakat must be paid every year at the rate of $2.5 \%$.

Furthermore, a standard accounting has a very close relationship to zakat payments in terms of simplifying zakat formulation. Internationally, the Accounting and Auditing Organization of Islamic Financial Institutions (AAOIFI) has published a Financial Accounting Standard for zakat (FAS 9) already in effect since 1 January 1999. The document outlines quite comprehensive standards for zakat accounting as an Islamic financial institution.

Nonetheless, in [2] contends that the AAOIFI FAS 9 is rather limited in the Malaysian context. 
As mentioned before, the AAOIFI-issued standard can be applied only to IFIs or Islamic Financial Institutions. Based on this condition, it has a limited range in companies and partnerships. Consequently, AAOIFI FAS 9 may not be immediately applied to other entities. Howevers, there are two types of zakat measurement that are recommended by FAS 9s. They are the the net assets (net current assets) and the net invested funds (net owner equity) methods. Both suggested methods produce the desired outcome. The first method considers all cash, assets acquired for trading, receivables net of doubtful debts and net financing assets (excluding unearned income) to be assets. Fixed assets and long-term investments are excluded. Thus, the zakatable amount is all assets minus the fixed assets, intangibles, current liabilities and long-term investments. Under the second method, the invested funds include paid-up capital, reserves, general provisions (investment risks), maintained earnings, net income and long-term liabilities. Thus, the zakatable amount is the whole amount minus the net fixed assets, investment not earned from trading and any other losses.

Meanwhile, at the Malaysian level, zakat is refeenced in the 1967 Income Tax Act, especially in section 44 (11A). In 2005, related to the amount of zakat should be paid by a company, the government had already permitted it to be calculated at 2,5\% of overall income [2].

Later, the Malaysian Accounting Standard Board (MASB) released TR i-1 (Technical Release i-1 on "Accounting for Zakat on Business"), an accounting pronouncement for corporate zakat effective since 1 July 2006. The accounting pronouncement focuses on facilitating the zakat calculation for businesses that can be utilized by companies from various industries.

Though TR i-1 stressed zakat calculation because most of business-related zakat issues fall under the SIRC's jurisdiction (and thus are considered beyond the purview of MASB), TR i-1 only handles financial reporting issues regarding the zakat of a corporation [2]. Other deductions on the zakat of corporation made by an entity (including issues such as zakat chargeability, calculation, determination of the zakat base and eligibility of assets and liabilities) should be subject to the conclusions achieved in cooperation with the respective zakat center. Therefore, it is crucial to note that TR i-1 only provides guidance on commonly held principles of accounting to solve a specific accounting issue, thus lacking legal enforcement [1].

However, The MASB Technical Release i-1 suggested two methods of zakat accounting 
calculation. namely Adjusted Working Capital Method (syari'ah) and Adjusted Growth Method (urfi'ah). Nowadays, the zakat payment practised by accountants in Malaysia is based on adjusted working capital [1]. Importantly, those two methods would eventually give the same calculation of zakat base.

Furthermore, a serious problem related to zakat data is that there is no common standards for calculating zakat payments by corporations in Malaysia. In spite of the MASB TR i-1, firms will exhibit stress in their financial statements. There is no punishment if firms do not comply with that guidance.

Based on empirical research by [1], among 33 listed Government Link Companies (GLCs) in Malaysia, the guidelines of TR i-1 were not being followed. For instance, in one of the GLCs in Malaysia, their zakat calculation is not made according to the net current assets as suggested by the guidelines but rather based on profit after tax. Accordingly, it can be concluded that GLC practice was entirely different and did not follow TR i-1.

\section{METHODOLOGY}

\subsection{Modeling of Corporate Zakat}

As discussed previously, capital structure of a firm is an important aspect that must be decided by the managers as it will ultimately relate to the firm's value. How a manager determines the composition of capital structure is an important task. However, further discussion will focused on development of a theoretical model that considers the objectives of the study as described earlier, especially in terms of the influence of zakat on capital structure decisions.

Furthermore, the theoretical model to develop the relationship between zakat and firm's capital structure is adopted from [7]. Several modifications will be introduced. The modifications involved the construction of a static capital structure model in the presence of zakat. In addition, the modifications also incorporated the modes of Islamic debt and equity financings. The model captures the essence of the tax advantage and bankruptcy cost trade-off models of $[19,21,32]$; the agency cost of debt arguments of [17-18, 28-29]; the potential loss of non-debt tax shields in non-default states in [8]; the differential personal tax rates between income from stocks and bonds in [23] and the extensions of Miller's model by [7-8, 20, 24-25]. 
However, the model involves zakat payment as an Islamic instrument due to the modeling of the Islamic capital structure. In a nutshell, the model will treat zakat as non-tax shield that has expected effects on finance decisions.

Regarding the purpose of developing an Islamic capital structure, this study employs the original model from [7], then extends that model to considering zakat payments. More importantly, to develop a model that represents the current state in the theory of optimal capital structure, the following assumptions have to be fulfilled:

1. Investors are risk-neutral.

2. Investors face a progressive tax rate on returns from bonds $\left(\mathrm{t}_{\mathrm{pb}}\right)$, while the firm faces a constant corporate tax rate $\left(\mathrm{t}_{\mathrm{c}}\right)$ and also faces a constant zakat rate $\left(\mathrm{z}_{\mathrm{c}}\right)$.

3. Corporate and personal taxes are based on end-of-period wealth. Consequently, debt payments (interest and principal) are fully deductible in calculating the firm's end-of-period tax bill, and are fully taxable at the level of the individual bondholder.

4. Equity returns (dividends and capital gains) are taxed at a constant rate, $\mathrm{t}_{\mathrm{ps}}$.

5. There exist a non-debt tax shield such as accelerated depreciation and investment tax credits, that reduce the firm's end-of-period tax liability.

6. Negative tax bills (unused tax credits) are not transferrable (saleable) either through time or across firms.

7. The firm will incur various costs associated with financial distress should it fail to meet, in full, the end-of-period payment promised to its bondholders.

8. The firm's end-of-period value before taxes and debt payments $(\widetilde{\mathrm{X}})$ is a random variable. If the firm fails to meet the debt obligation to its bondholders $(\hat{Y})$ the costs associated with financial distress will reduce the value of the firm by a constant fraction $\mathrm{k}$.

Furthermore, under the above assumptions of the model, the uncertain end-of-period pre-tax returns to the firm's stockholders and bondholders can be written as follows:

\subsection{Cash Flow of Debt and Equity after Corporate Tax and Zakat Payment}

$$
\tilde{Y}_{s}=\left\{\begin{array}{cl}
(\tilde{X}-\hat{\mathrm{Y}})\left(1-t_{c}\right)+\phi-z_{c}(\tilde{X}), & \tilde{\mathrm{X}} \geq \hat{\mathrm{Y}}+\phi / \mathrm{t}_{\mathrm{c}} \\
\tilde{X}-\hat{\mathrm{Y}}-z_{c}(\tilde{X}), & \hat{\mathrm{Y}} \leq \tilde{\mathrm{X}}<\hat{\mathrm{Y}}+\phi / \mathrm{t}_{\mathrm{c}} \\
0, & \widetilde{\mathrm{X}}<\hat{\mathrm{Y}}
\end{array}\right.
$$




$$
\tilde{Y}_{b}=\left\{\begin{array}{cl}
\hat{\mathrm{Y}}, & \widetilde{\mathrm{X}} \geq \hat{\mathrm{Y}} \\
\widetilde{\mathrm{X}}(1-\mathrm{k})-\mathrm{z}_{\mathrm{c}}(\widetilde{\mathrm{X}}), & 0 \leq \widetilde{\mathrm{X}}<\hat{\mathrm{Y}} \\
0, & \widetilde{\mathrm{X}}<0
\end{array}\right.
$$

where $\widetilde{Y}_{b}, \widetilde{Y}_{s}=$ the gross end-of-period returns to bondholders and stockholders respectively, $\widetilde{X}=$ The firm's end-of-period value before taxes and debt payments, $\hat{Y}=$ the total end-of-period promised payment to bondholders, $\phi=$ the total after-tax value of the non-debt shields if they are fully utilized at the end-of-period, $\mathrm{t}_{\mathrm{c}}=$ corporate tax rate, $\mathrm{z}_{\mathrm{c}}=$ corporate zakat rate and $\mathrm{k}$ $=$ costs of financial distress of end-of-period value of the firm.

The model modification above incorporates zakat payment as a non-tax shield. Zakat payments are calculated based on firm's earnings before taxes and debt payments. More spesifically, Equation (10) shows that if pre-tax earnings are large enough for the firm to fully utilize the non-debt tax shield $\left(\phi / t_{c}\right)$, then the gross end-of-period return to stockholders is $\left(\widetilde{X}-\hat{Y}-\phi / t_{c}\right)\left(1-t_{c}\right)+\phi / t_{c}-z_{c}(\widetilde{X})=(\widetilde{X}-\hat{Y})\left(1-t_{c}\right)+\phi-z_{c}(\widetilde{X})$. Then, if the firm's

pre-tax earnings are such that $\widetilde{X}-\hat{Y}-\phi / t_{c}<0$, the firm will pay no tax but will still pay zakat and Assumption 6 implies that the end-of-period return to stockholders is $\widetilde{X}-\hat{Y}-z_{c}(\widetilde{X})$. Meanwhile, the end-of-period pre-tax return to bondholders in Equation (11) follows from Assumption 8 and bondholders have limited liability in the event that the firm's end-of-period value $\widetilde{\mathrm{X}}$ is negative.

\section{RESULTS AND DISCUSSION}

According to Assumption 1 that of risk neutrality, Equations (10) and (11) provide the following beginning-of-period market value of the firm's stocks (S) and bonds (B):

$$
\begin{aligned}
& \mathrm{S}=\mathrm{E}\left(\widetilde{\mathrm{Y}}_{\mathrm{s}}\right) / \mathrm{E}\left(\widetilde{\mathrm{r}}_{\mathrm{s}}\right)=\frac{1-\mathrm{t}_{\mathrm{ps}}}{\mathrm{r}_{\mathrm{o}}} \\
& {\left[\int_{\hat{\mathrm{Y}}+\phi / \mathrm{t}_{\mathrm{c}}}^{\infty}\left[(\widetilde{\mathrm{X}}-\hat{\mathrm{Y}})\left(1-\mathrm{t}_{\mathrm{c}}\right)+\phi-\mathrm{z}_{\mathrm{c}}(\widetilde{\mathrm{X}})\right] \mathrm{f}(\widetilde{\mathrm{X}}) \mathrm{d} \widetilde{\mathrm{X}}+\int_{\hat{\mathrm{Y}}}^{\hat{\mathrm{Y}}+\phi / \mathrm{t}_{\mathrm{c}}}(\widetilde{\mathrm{X}}-\hat{\mathrm{Y}})-\mathrm{z}_{\mathrm{c}}(\widetilde{\mathrm{X}}) \mathrm{f}(\widetilde{\mathrm{X}}) \mathrm{d} \widetilde{\mathrm{X}}\right]}
\end{aligned}
$$

where

$B=\frac{E\left(\widetilde{Y}_{b}\right)}{E\left(\widetilde{r}_{b}\right)}=\frac{1-t_{p b}}{r_{o}}$ 
$\left[\int_{\hat{Y}}^{\infty} \hat{Y} f(\widetilde{X}) d(\widetilde{X})+\int_{0}^{\hat{Y}} \widetilde{X}(1-k)-z_{c}(\widetilde{X}) f(\widetilde{X}) d(\widetilde{X})\right]$

where $S, B=$ the market value of the firm's stocks and bonds respectively, $E\left(\widetilde{r}_{s}\right), E\left(\widetilde{r}_{b}\right)=$ one plus the expected pre-tax rate of return from stocks and bonds respectively, $r_{0}=$ one plus the rate of return on default-free, tax-exempt bonds, $f(\widetilde{X})=$ probability density of $\widetilde{X}, t_{p s}=$ equity returns (dividends and capital gains) are taxed at a constant rate and $t_{\mathrm{pb}}=$ progressive tax rate on returns from bonds.

Furthermore, adding Equation (12) and (13) yields the market value of the firm (V):

$$
\begin{aligned}
V=\frac{1}{r_{o}}[(1- & \left.t_{p b}\right) \int_{0}^{\hat{Y}} \widetilde{X}(1-k)-z_{c}(\widetilde{X}) f(\widetilde{X}) d(\widetilde{X}) \\
& +\int_{\hat{Y}}^{\hat{Y}+\phi / t_{c}}\left[\left\{(\widetilde{X}-\hat{Y})-z_{c}(\widetilde{X})\right\}\left(1-t_{p s}\right)+\hat{Y}\left(1-t_{p b}\right)\right] f(\widetilde{X}) d(\widetilde{X}) \\
& +\int_{\hat{Y}+\phi / t_{c}}^{\infty}\left[\left\{(\widetilde{X}-\hat{Y})\left(1-t_{c}\right)+\phi-z_{c}(\widetilde{X})\right\}\left(1-t_{p s}\right)+\hat{Y}(1\right. \\
& \left.\left.\left.-t_{p b}\right)\right] f(\widetilde{X}) d(\widetilde{X})\right]
\end{aligned}
$$

Equation (14) shows that the value of the firm is equal to the present value of the sum of three expected values (integrals). The first integral represents the situation in which is $\widetilde{\mathrm{X}}$ positive but insufficient to meet its debt obligation. Under this condition, the payment to the firm's bondholders is $\widetilde{\mathrm{X}}$ minus total costs of financial distress, $\mathrm{k} \widetilde{\mathrm{X}}$ and then minus total zakat payments of the firm's end-of-period value before taxes and debt payments $z_{c} \widetilde{X}$. Consistent with the assumption of a wealth tax, the payment to the firm's bondholders and net of costs of financial distress is subject to the personal tax rate $\left(\mathrm{t}_{\mathrm{pb}}\right)$.

These integrals represent a state in which the firm's end-of-period pre-tax value $(\widetilde{\mathrm{X}})$ is greater than its debt obligation $(\hat{Y})$, but less than the maximum level of earnings that would result in a zero end-of-period corporate tax bill $\left(\hat{Y}+\phi / t_{c}\right)$. In these conditions, the firm has no corporate tax bill. However, the payments to bondholders and stockholders are subject to personal tax rates. Finally, the third integral defines the after-tax cash flow to the firm's security holders if earnings are sufficient to pay bondholders and to generate a positive corporate tax liability. 
Furthermore, the firm's optimal leverage decision involves setting $\hat{Y}$, the end-of-period payment promised to bondholders such that the market value of the firm is maximized. Differentiating (5) with respect to $\hat{Y}$ yields the first-order condition of Equation (15) where $\mathrm{V}_{\hat{\mathrm{Y}}}$ is the partial derivative $\partial \mathrm{V} / \partial \hat{\mathrm{Y}}$.

$$
\begin{aligned}
\mathrm{V}_{\hat{\mathrm{Y}}}=\frac{\left(1-\mathrm{t}_{\mathrm{pb}}\right)}{\mathrm{r}_{\mathrm{o}}}\left[\left\{-\mathrm{k}-\mathrm{z}_{\mathrm{c}}+\frac{\left(1-\mathrm{t}_{\mathrm{ps}}\right) \mathrm{z}_{\mathrm{c}}}{\left(1-\mathrm{t}_{\mathrm{pb}}\right)}\right\} \hat{\mathrm{Y}} \cdot \mathrm{f}(\hat{\mathrm{Y}})\right. \\
+\left\{(1-\mathrm{F}(\hat{\mathrm{Y}}))\left(1-\frac{\left(1-\mathrm{t}_{\mathrm{ps}}\right)\left(1-\mathrm{t}_{\mathrm{c}}\right)}{\left(1-\mathrm{t}_{\mathrm{pb}}\right)}\right)\right. \\
\left.\left.-\frac{\left(1-\mathrm{t}_{\mathrm{ps}}\right)}{\left(1-\mathrm{t}_{\mathrm{pb}}\right)} \mathrm{t}_{\mathrm{c}}\left(\mathrm{F}\left(\hat{\mathrm{Y}}+\frac{\phi}{\mathrm{t}_{\mathrm{c}}}\right)-\mathrm{F}(\hat{\mathrm{Y}})\right)\right\}\right]
\end{aligned}
$$

where $\mathrm{F}$ is the cumulative of probability density function of $\widetilde{\mathrm{X}}$.

The first term in Equation (15) represents the marginal net tax advantage of debt, while the second and third terms represent marginal expected leverage-related costs. The optimal leverage involves balancing the net tax advantege of debt against leverage-related costs, non-debt tax shields and zakat.

\section{CONCLUSION}

Based on the deveoped model, we can utilize the comparative statics analysis. The comparative statics of the leverage relevancy model can be shown by differentiating the optimally condition (15) with respect to each of the relevant exogenous variables. Differentiating $V_{\hat{Y}}$ in (15) with respect to $z_{c}, k, \phi, t_{p s}$ and $t_{p b}$ yields the following cross-partial derivatives:

$$
\begin{aligned}
\mathrm{V}_{\hat{\mathrm{Y} Z c}} & =\frac{\left[-\left(1-\mathrm{t}_{\mathrm{pb}}\right)-\left(1-\mathrm{t}_{\mathrm{ps}}\right)\right] \hat{\mathrm{Y}} \mathrm{f} f(\hat{\mathrm{Y}})}{\mathrm{r}_{\mathrm{o}}}<0 \quad(16) \\
\mathrm{V}_{\hat{\mathrm{Y}} \mathrm{k}} & =\frac{-\left(1-\mathrm{t}_{\mathrm{pb}}\right) \hat{\mathrm{Y}} \mathrm{f}(\hat{\mathrm{Y}})}{\mathrm{r}_{\mathrm{o}}}<0 \quad(17) \\
\mathrm{V}_{\hat{\mathrm{Y}} \phi} & =\frac{-\left(1-\mathrm{t}_{\mathrm{ps}}\right) \mathrm{f}\left(\hat{\mathrm{Y}}+\frac{\phi}{\mathrm{t}_{\mathrm{c}}}\right)}{\mathrm{r}_{\mathrm{o}}}<0(18) \\
\mathrm{V}_{\hat{\mathrm{Y}} \mathrm{t}_{\mathrm{ps}}} & =\frac{\left\{[1-\mathrm{F}(\hat{\mathrm{Y}})]-\mathrm{t}_{\mathrm{c}}\left[1-\mathrm{F}\left(\hat{\mathrm{Y}}+\frac{\phi}{\mathrm{t}_{\mathrm{c}}}\right)\right]\right\}}{\mathrm{r}_{\mathrm{o}}}>\frac{\left(1-\mathrm{t}_{\mathrm{c}}\right)[1-\mathrm{F}(\hat{\mathrm{Y}})]}{\mathrm{r}_{\mathrm{o}}}>\frac{\hat{\mathrm{Y}} \cdot \mathrm{f}(\hat{\mathrm{Y}})}{\mathrm{r}_{\mathrm{o}}}>0 \\
\mathrm{~V}_{\hat{\mathrm{Y}} \mathrm{t}_{\mathrm{pb}}} & =\frac{\left(-\mathrm{k}-\mathrm{z}_{\mathrm{c}}\right) \hat{\mathrm{Y}} . \mathrm{f}(\hat{\mathrm{Y}})-[1-\mathrm{F}(\hat{\mathrm{Y}})]}{\mathrm{r}_{\mathrm{o}}}<0(20)
\end{aligned}
$$

The cross-partial derivatives in Equations (16)-(20) are negative. However, there will be a rise 
in term of zakat payment, financial distress cost and also non-debt tax shield (NDTS). All of those three items can lead to a decreasing of the optimal debt level.

Further, the comparative statics provide the following testable implications:

1. The optimal level of debt has inversely a very clese relation toward corporate zakat payment.

2. The optimal level of debt has conversaly a very close relation over financial distress costs, where cost of bankrupty and the agency of costs of debt involved.

3. The optimal level of debt has conversly a close connection toward the level of NDTS, which stands for Non-Debt Tax Shields.

4. The optimal level of debt has a highly relation over the equity of personal tax rate.

5. The optimal level of debt is inversely connected to the tax rate of marginal bondholder.

\section{ACKNOWLEDGEMENTS}

This project is funded by the Research Acculturation Collaborative Effort (RACE) Grant Scheme of Ministry of Higher Education Malaysia (MOHE) (Vot number: RACE 56007). Our special appreciation to the MOHE and Universiti Malaysia Terengganu for supporting this research.

\section{REFERENCES}

[1] Ibrahim A, Abdullah A A, Kadir M R, AdwamWafa S M. Assessing financial reporting on adopting business zakat guidelines on Malaysian Government Linked Companies. International Journal of Business and Social Science, 2012, 3(24):220-229

[2] Bakar N B. A zakat accounting standard (ZAS) for Malaysian companies. American Journal of Islamic Social Sciences, 2007, 24(4):74-92

[3] Aggarwal R. International differences in capital structure norms: An empirical study of large European companies. Management International Review, 1994, 34:5-18

[4] Akhyar A M, Barizah A B N. Accounting treatment for corporate zakat: A critical review. International Journal of Islamic and Middle Eastern Finance and Management, 2009, 2(1):32-45

[5] Anderson C W, Makhija A K. Deregulation, disintermediation, and agency costs of debt: Evidence from Japan. Journal of Financial Economics, 1999, 51(2):309-339 
[6] Booth L, Aivazian V, Demirguc-Kunt A, Maksimovic V. Capital structures in developing countries. Journal of Finance, 2001, 56(1):87-130

[7] Bradley M, Jarrell G A, Kim E. On the existence of an optimal capital structure: Theory and evidence. Journal of Finance, 1984, 39(3):857-878

[8] DeAngelo H, Masulis R W. Optimal capital structure under corporate and personal taxation. Journal of Financial Economics, 1980, 8(1):3-29

[9] Elton E J, Gruber M J. Marginal stockholder tax rates and the clientele effect. Review of Economics and Statistics, 1970, 52(1):68-74

[10]Fama E F, French K R. Value versus growth: The international evidence. Journal of Finance, 1998, 53(6):1975-1999

[11]Fischer E O, Heinkel R, Zechner J. Dynamic capital structure choice: Theory and tests. Journal of Finance, 1989, 44(1):19-40

[12]Ghosh A, Cai F, Li W. The determinants of capital structure. American Business Review, 2000, 18(2):129-132

[13]Graham J R. Do personal taxes affect corporate financing decisions? Journal of Public Economics, 1999, 73(2):147-185

[14]Graham J R, Harvey C R. The theory and practice of corporate finance: Evidence from the field. Journal of Financial Economics, 2001, 60(2):187-243

[15]Harris M, Raviv A. The theory of capital structure. Journal of Finance, 1991, 46(1):297-355

[16]Haugen R A, Senbet L W. The insignificance of bankruptcy costs to the theory of optimal capital structure. Journal of Finance, 1978, 33(2):383-393

[17]Jensen MC, Meckling WH. Theory of the firm: Managerial behavior, agency costs and ownership structure. Journal of Financial Economics, 1976, 3(4):305-360

[18]Jensen M C. Agency costs of free cash flow, corporate finance, and takeovers. The American Economic Review, 1986, 76(2):323-329

[19]Kim E H. A mean-variance theory of optimal capital structure and corporate debt capacity. Journal of Finance, 1978, 33(1):45-63

[20]Kim E H. Miller's equilibrium, shareholder leverage clienteles, and optimal capital structure. Journal of Finance, 1982, 37(2):301-319

[21]Kraus A, Litzenberger R H. A state-preference model of optimal financial leverage. Journal of Finance, 1973, 28(4):911-922

[22]MacKie-Mason J K. Do taxes affect corporate financing decisions? Journal of Finance. 1990, 45(5):1471-193 
[23]Miller M H. Debt and taxes. Journal of Finance, 1977, 32(2):261-275

[24]Modigliani F, Miller M H. The cost of capital, corporation finance and the theory of investment. American Economic Review, 1958, 48(3):261-297

[25]Modigliani F, Miller M H. Corporate income taxes and the cost of capital: A correction. American Economic Review, 1963, 53(3):433-443

[26]Myers S C. Determinants of corporate borrowing. Journal of Financial Economics, 1977, 5(2):147-175

[27]Myers S C. The capital structure puzzle. Journal of Finance, 1984, 39(3):574-592

[28]Myers S C, Majluf N S. Corporate financing and investment decisions when firms have information that investors do not have. Journal of Financial Economics, 1984, 13(2):187-221

[29]Myers SC. Capital structure. Journal of Economic Perspectives, 2001, 15(2):81-102

[30]Naidu G N. Capital structure strategies of Australian and South African firms. Management International Review, 1986, 26(2):52-61

[31]Rajan R G, Zingales L. What do we know about capital structure? Some evidence from international data. Journal of Finance, 1995, 50(5):1421-1460

[32]Scott Jr J H. A theory of optimal capital structure. Bell Journal of Economics, 1976, $7(1): 33-54$

[33] Shyam-Sunder L, Myers SC. Testing static tradeoff against pecking order models of capital structure. Journal of Financial Economics, 1999, 51(2):219-44

[34]Titman S, Wessels R. The determinants of capital structure choice. Journal of Finance, 1988, 43(1):1-9

[35]Yang J, Davis GC, Leatham DJ. Impact of interest rate swaps on corporate capital structure: An empirical investigation. Applied Financial Economics, 2001, 11(1):75-81 [36]Othman H J. Zakat and tax treatment. In National Business Zakat Symposium, 2013 [37]Azura B T, Sanusi N. The dynamics of capital structure in the presence of zakat and corporate tax. International Journal of Islamic and Middle Eastern Finance and Management, 2014, 7(1):89-111

\section{How to cite this article:}

Sanusi N A, Talattov A G, Kusairi S, Nor A H S M. Modeling of zakat in the capital structure theory. J. Fundam. Appl. Sci., 2017, 9(6S), 900-916. 